University of Nebraska - Lincoln

DigitalCommons@University of Nebraska - Lincoln

Faculty Publications: Department of Teaching, Department of Teaching, Learning and Teacher Learning and Teacher Education

Education

$12-2013$

\title{
Media discourse and dual language programs: A critical linguistic analysis
}

Theresa Catalano

University of Nebraska-Lincoln, tcatalano2@unl.edu

Aleidine Kramer Moeller

University of Nebraska-Lincoln, amoeller2@unl.edu

Follow this and additional works at: https://digitalcommons.unl.edu/teachlearnfacpub

Catalano, Theresa and Moeller, Aleidine Kramer, "Media discourse and dual language programs: A critical linguistic analysis" (2013). Faculty Publications: Department of Teaching, Learning and Teacher Education. 142.

https://digitalcommons.unl.edu/teachlearnfacpub/142

This Article is brought to you for free and open access by the Department of Teaching, Learning and Teacher Education at DigitalCommons@University of Nebraska - Lincoln. It has been accepted for inclusion in Faculty Publications: Department of Teaching, Learning and Teacher Education by an authorized administrator of DigitalCommons@University of Nebraska - Lincoln. 


\title{
Media discourse and dual language programs: A critical linguistic analysis
}

\author{
Theresa Catalano ${ }^{1}$ and Aleidine J. Moeller ${ }^{2}$ \\ 1. University of Nebraska-Lincoln, Henzlik 27, Lincoln, NE 68588, USA \\ 2. University of Nebraska-Lincoln, Henzlik 115, Lincoln, NE 68588, USA \\ Corresponding author - T. Catalano, tel 402 472-2229, fax 402 472-2837 \\ Email addresses - T. Catalano: tcatalano2@unl.edu, theresacatalano@gmail.com; A. J. Moeller: amoeller2@unl.edu
}

\begin{abstract}
Much research exists that discusses the benefits of dual language education (DLE) as well as the political, historical and social factors involved in the implementation (or lack of) of DLE in the United States. However, little attention has focused on how these programs are presented in media discourse. This study aims to fill this gap by examining media discourse and how DLE is currently relayed to the public. Twenty-nine online articles from US news sources were collected and analyzed as regards linguistic strategies used in media discourse of DLE. Findings reveal the prevailing metaphors used in multilingual/monolingual discourse to be LANGUAGE/ ENGLISH AS WATER and DLE AS BUSINESS/FACTORY. Other significant findings include the frequent use of linguistic strategies such as metonymy, pre-suppositions, legitimization and deictics. Based on these findings, the authors offer suggestions of how discourse can be adapted to expand and improve communication about DLE in future media discourse.
\end{abstract}

Keywords: Dual language education, Media discourse, Critical linguistic analysis

\section{Introduction and background}

Although multilingualism/pluralism is the norm around the globe, US schools remain largely monolingual in their orientation. According to a recent survey, $20.8 \%$ of the US population speaks a language other than English in their homes (Language Spoken at Home, 2011). Yet currently only 422 dual language (DL) programs exist across the United States (Center for Applied Linguistics, 2012) and only 10\% of US residents say they speak a language other than English well (Robinson et al., 2006). While much attention has been given to political, historical, and social factors as regards why this is the case (Skutnabb-Kangas et al., 2009), few studies have examined how media discourse might affect the willingness to support DL programs.

It is essential to understand the types of discourses that exist in the media regarding language education and policies in order to better understand how support for DL programs can be garnered. By discourses, we mean the broader ideas communicated by a text ( Fairclough, 2000; van Dijk, 1993; Wodak, 2001) that can affect our views of the world (Foucault, 1981). According to de Jong (2013), language education policies in the United States have "varied significantly over time, and have been shaped by assimilationist (monolingual) and pluralist (multilingual) views of the role of linguistic and cultural diversity in schools" (p. 98). Currently, there exists a dominance of monolingual discourses, although pluralistic spaces are continually being made in an attempt to re- sist these monolingual trends (de Jong, 2013). de Jong (2013) traces the historical development of this discourse from pluralist discourses at the time of European colonization in North America to early assimilationist discourses in the late 19th and early 20th centuries. These discourses have led to the current assimilationist present with pluralist edges and the emergence of initiatives such as California's Proposition 227 and Arizona's 203 and the inclusion of monolingual discourses such as the "English only" movement. de Jong (2013) suggests educators and policymakers construct more pluralist discourses that affirm cultural identities and promote additive multilingual learning environments.

Numerous studies describe media discourse and how it shapes language policies and reflects public opinion about them. Johnson (2005a \& 2005b) examined rhetorical strategies used to promote Arizona Proposition 203 (English for the Children) and noted how the metaphor of WAR was purposely implemented to construct a context of violence and heroism in which monolingual discourses prevailed (Johnson, 2005a). In addition, he found metaphors referring to the target domain of BILINGUAL EDUCATION contained source domains such as TRAP, SEGREGATION, FAILURE AND INDUSTRY whereas metaphors referring to English and English immersion programs had source domains of SUCCESS and GIFT (2005b). McCarty (2004) identified the paradox between the value placed on foreign language instruction in US schools and the simultaneous devaluing of those same "foreign" languages among indigenous and immigrant minorities. McCarty sees these policy contradictions as responses to larger 
political, socioeconomic and demographic forces. Thus, when linguistic and cultural differences are seen by dominant forces as "safe" (such as in the colonial United States), pluralism is supported and tolerated (Heath, 1992), but when it is seen as threatening (such as in the case of enslaved Africans who were systematically denied language), the opposite occurs. Referred to as "language panics" by Hill (2001), this type of monolingual discourse and the resulting policies is about social class, power and control (McCarty, 2004).

Many scholars have examined the media's representation of monolingual discourses in initiatives such as Proposition 227 (California) and 203 (Arizona) (Capetillo-Ponce, 2002; Galindo, 1997; Johnson, 2005a, 2005b; Macedo et al., 2003; Media Alliance, 1998; Santa Ana, 2002; Wright, 2005). One important finding of these studies was that supporters of the English-only initiatives expressed concern about national unity as a result of immigrants maintaining their native languages (de Jong, 2013). McQuillan and Tse (1996) examined opinion pieces discussing bilingual education and identified a link between discourse about bilingual education and immigration issues where opposition to bilingual education was closely linked to a larger concern about immigration in the United States. The authors found that the majority of the opinion pieces opposed to bilingual education failed to examine existent empirical evidence collected by experts in the field that demonstrated their effectiveness (McQuillan and Tse, 1996, p. 20). Instead, media discourse focused on personal or anecdotal accounts from elite members of society, or individuals involved in the program. The authors posited that the inclusion of these anecdotes, as opposed to results from empirical studies, might be due to their effectiveness as persuasive devices to the general public. These findings suggest that academics must do a better job disseminating their research about these programs to the public due to the potential impact these studies can have on policy decisions.

Other important work in this area includes Santa Ana's (2002) study of metaphors of Latinos in American public discourse exposed frequent metaphors related to education (and in particular, education of Latino youth as discussed in media discourse about Proposition 227). These metaphors included the dominant way of characterizing student learning as an EMPTY VESSEL, which expands to EDUCATION AS A FACTORY, BUSINESS, PATH/RIVER (e.g. mainstream), all of which "do not construct American values of the inherent worth of every child" (p. 196). In the case of metaphors of language, Santa Ana found the metaphor of LANGUAGE AS WATER that represents how people conceive of language as a fluid medium into which meanings or ideas are injected. In the case of discourse about bilingualism, Santa Ana found that in discourse about language use and language acquisition, WATER terms were plentiful (e.g. absorb, fluent) and used to establish semantic associations between the complex and commonly experienced everyday substance, WATER, and this pivotal feature of life, LANGUAGE.

These metaphors help us to make sense of this complex concept through this everyday resource and to conceive of it as a powerful substance that can be channeled.

However, both proponents and opponents of Prop. 227 adopted some of the lexical items that lead to this metaphor, thus leading to confusion. For example, the term immersion was used to refer to English-only instruction (e.g. English immersion) or Sheltered English Immersion (SEI), but also for DL programs (referred to as "bilingual education" at the time) such as "two-way immersion". These two types of programs vary vastly in goals and theory. In the case of English-only/SEI, the transition to English as quickly as possible is promoted without the benefit of L1 maintenance. Furthermore there is no tie to second language acquisition research and a general lack of understanding of the language acquisition process it- self as well as the length of time required to learn a language. On the other hand, bilingual education discourse about "twoway immersion" and "immersion programs" is used in a multilingual discourse context based on current research where all languages are valued, and there is a complete pedagogy through which language learning can be optimally facilitated. According to Santa Ana, English-only/SEI approaches to the use of these words stem from the metaphor of LANGUAGE AS BARRIER, in which English is given special status among languages. In this case, the metaphor used is ENGLISH AS WATER (as opposed to LANGUAGE AS WATER), which encompasses the mistaken view that children rapidly acquire language and this automatic process passively carries immigrant students along with its current (e.g. mainstream) to academic English fluency (Santa Ana, 2002).

This connection to immigrants is not accidental. In Santa Ana's analysis of discourse related to Proposition 187 (prohibiting local governments from providing services such as health care to undocumented immigrants) IMMIGRATION AS DANGEROUS WATERS was found to be the dominant metaphor. Santa Ana posits that this metaphor not only characterizes the movement of people as moving water (that we should fear), but "does not refer to any aspect of the humanity of immigrants" (p. 73). By mapping the characteristics of dangerous water onto immigrants, the metaphor encourages a correspondence of natural actions such as stemming the tide and trying to dam this flow by stopping immigration (thus highlighting negative effects and ignoring positive ones). Later in his book, Santa Ana (2002) shows how this aggregation of individuals into an undifferentiated mass quantity through water metaphors has entered educational discourse. Hence, when referring to the education of English language learners, ENGLISH IS WATER becomes a common metaphor and has a negative effect because it links discourse about language learning to discourse of dangerous waters as well as EDUCATION AS RIVER. This use of water metaphors (e.g. English immersion) communicates misinformation about the process of language acquisition and portrays languages other than English as barriers. While Santa Ana does provide a comprehensive analysis of public discourse related to immigration and language policies such as Prop. 227, his analysis was conducted during the late 1990s when the term "dual language education" (DLE) was not commonly used, and he did not specifically examine discourse related to DL programs in general. Recently, the new umbrella term for bilingual education has changed to "dual language" reflecting an effort to avoid association with past controversy and negative coverage of bilingual education (Lesow-Hurley, 2013).

A final study relevant to the present paper is that of Krashen (2004) in which he addresses the topic of communication about DL programs by attributing the limited interest shown in such programs to a lack of organized effort to inform the public rather than negative attitudes toward these programs. He urges bilingual educators to improve efforts to communicate with the media and the public in general using both traditional and digital means (such as letters to the editor) in order to highlight the compelling evidence why DLE is beneficial. Although Krashen concludes that communication needs to be improved, he does not attempt to analyze texts representing these programs, nor does he offer to improve the actual communication in the detailed manner that discourse analysis permits.

The present paper aims to fill this gap in the literature by examining how DL programs are currently represented to the public. As the initial section of this three-part study, this paper will detail the linguistic strategies found in the text that represent DL programs and those involved. The second and third sections of the study (to be published later) will explore the non-linguistic strategies in media discourse as well as reader comments. The analysis of 29 online newspaper articles with the topic of DLE will focus on metaphor, metonymy and other 
linguistic strategies such as pre-suppositions, legitimization and deictics used to represent these programs. It is the intent that such an analysis reveal not only how these programs are currently represented in media discourse but also how we can better communicate about these programs to further develop, promote, and expand such efforts.

\section{Theoretical frames}

In order to understand media discourse regarding DL programs, instruments of analysis must be employed that assist in unpacking the structure of the discourse. This requires tools that can chip away at text and get below the "tip of the ideological iceberg" at grammatical structure and linguistic strategies that permit us to understand how these programs are conceptualized via the discourse (van Dijk, 1997). Critical Discourse Analysis (CDA) and Cognitive Linguistics (CL) offer such frameworks and tools from which useful elements can be extracted and combined to analyze media discourse. A very brief overview of these scholarly perspectives/approaches will provide general background of the research lens used in this study.

\subsection{Critical discourse analysis (CDA)}

CDA is a scholarly perspective on the study of language that "critically analyzes discourse - that is to say language in useas a means of addressing social change" (Scollon, 2001, p. 140). Critical Discourse Analysis (CDA) allows us to look at how text and talk function politically (as well as in social interactions) and argues that "... language-in-use is always part and parcel of, and partially constitutive of, specific social practices and that social practices always have implications for inherently political things like status, solidarity, the distribution of social goods, and power" (Gee, 2011, p. 68). CDA generally focuses on social problems, in particular, the role of discourse in the production and reproduction of power abuse or domination and studies the way in which ideology, identity, and inequality are (re) enacted through texts produced in social and political contexts (van Dijk, 2001). Thus, it serves as an excellent device used to identify manipulation and ideology in text that is "below the threshold of notice" (Fowler, 1991, p. 66).

\subsection{Cognitive linguistics (CL)}

Cognitive linguistics provides a powerful approach to the study of language that places attention on conceptual systems, human cognition and meaning construction (Hart, 2010). CL fits comfortably within CDA and provides a complementary approach that creates more depth in understanding the perceptions of the public (Fauconnier, 2002; Hart, 2010). Cognitive linguists posit that communication involves how we conceptualize language, and is based on the same system that we use in thought and action. Thus, linguistic structure provides indirect access to conceptual processes and is in this sense a "window to the mind" (Fauconnier, 1999; Hart, 2010). Metaphors and conceptual metaphor theory (Lakoff and Johnson, 1980) are central to CL. From this frame of reference, metaphors are considered to be a conceptual mapping from one semantic source domain (the more concrete and clearly organized domain) to a different semantic target domain that is more abstract and more difficult to talk about (e.g. characteristics of WATER mapped onto LANGUAGE, as discussed in Santa Ana (2002)). Metaphors are largely used unconsciously, and as the "backbone of language and thought" (Kövecses, 2006, p. 17) are essential tools we can use to reason about ourselves and our world, especially when we encounter abstract or complex concepts (Slingerland, 2004). To learn more about how metaphors are used in discourse about language, see Johnson, (2005a, 2005b) or Santa Ana (2002).

\section{Method}

Twenty-nine online news reports were selected from online versions of local papers and TV stations such as kmov.com (St. Louis) and utsandiego.com. A www.google.com search was conducted using the term "dual language" and articles that fit the following criteria were selected for inclusion in this study:

(1) Articles published within the time frame of 2012-2013. ${ }^{1}$

(2) Articles found using the search term "dual language" that mention "dual language" at least once in the article.

(3) Articles that adhered to a length of 150-2000 words.

(4) Articles derived from a news source (e.g. T.V. station "kmov.com") and not an educational source such as a school district or university resource center.

Articles found represented eleven states in the US including California, Texas, Illinois, Wyoming, Utah, Minnesota, North Carolina, Washington, Oregon and Kansas. These states vary greatly in the number and types of DL programs offered, with most of the articles reviewed featuring program growth and development, challenges or benefits to the community. Articles included in this study can be accessed in Appendix A by clicking on the links. Once articles were selected and located, they were converted to plain text format as one file and entered into AntConc3.2.4m (concordance program). First, a word list was produced to systematically determine patterns and frequencies of lexical items, which was then used by the authors to search for metaphors with target domains of LANGUAGE and DLE. Lists of metaphor tokens were then compiled-as per Santa Ana's (2002) model-and source domains were determined and compared with existing metaphor studies regarding language and language education metaphors (e.g. Santa Ana, 2002). After metaphors were determined from the word lists, they were searched again manually in context in order to interpret the characteristics of the tokens on the basis of ample context. Finally, dominant, secondary and occasional metaphors were categorized and tabulated, followed by a detailed analysis. In addition, after metaphors were categorized, additional linguistic strategies (e.g. legitimization) were located and coded after several in-depth readings of the text file. These are further discussed in detail in the following section.

\section{Findings}

Analysis has revealed dominant, secondary and occasional metaphors as well as other linguistic devices that are used to present DLE and its students to the public. Metaphors with target domain DLE and LANGUAGE/LANGUAGE LEARNERS are shown in Table 1 and Table 2 followed by a discussion of the dominant metaphors, their ontology, and accompanying narratives. Finally, important linguistic strategies used to represent these programs in media discourse are analyzed.

\subsection{Dominant metaphors}

The dominant metaphor of DLE/LANGUAGE AS WATER is not surprising given Santa Ana's similar findings (2002). In this metaphor, DLE programs can grow or stagnate and can receive an influx of students enrolled in immersion programs who are immersed in the language and become fluent. What is interesting is the presence of both multilingual and mono-

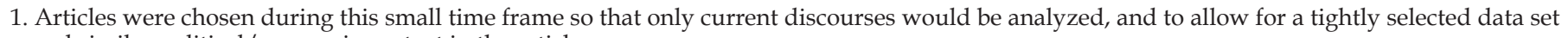
and similar political/economic context in the articles. 
Table 1. Metaphors with target domain ${ }^{3}$ Dual Language Education ${ }^{2}$.

\begin{tabular}{llcr}
\hline Type & Source domain & Totals & Percentage (\%) \\
\hline Dominant & Water e.g., immersion classrooms & 110 & 32 \\
& Business/factory e.g., global market, & 78 & 22.7 \\
competitive, skills, workforce & & \\
Secondary & Gift/resource e.g., resource, gift & 46 & 13.4 \\
& Cultivation e.g., thrive, blossom, roots & 25 & 7.3 \\
Occasional & Building, force, war, path, show, & & \\
& sport, natural, disaster, food & 85 & 24.7 \\
& & $344^{\mathrm{a}}$ & $100^{\mathrm{b}}$ \\
\hline
\end{tabular}

a. Total number of metaphors.

b. Total percentage.

lingual discourses and how both incorporate WATER metaphors. Results reveal that multilingual discourses in the corpus are commonly used to explain new DL programs and talk about successful programs while monolingual discourses are used to talk about the problems with past program models such as transitional bilingual models (or English-only). In the following examples, multilingual discourses in favor of DL programs put forward WATER metaphors that help us to conceive of language as part of our daily world and as a CONDUIT that helps students become fluent.

- Many of the kids at Los Altos are familiar with both of these worlds, and some will grow up fully fluent in the languages of both. This year, Los Altos helped them by starting a dual language immersion program. (Text 1 )

- Four years ago, the school started a charter program on campus that immerses students in Mandarin, with Spanish as the enrichment program. (Text 11)

- From Chula Vista to Laguna Niguel and Sacramento, public schools are creating dual-language immersion programs at a fast pace. (Text 2)

- The data for dual-language is clear, Ebert told the School Board on Jan. 28. Bilingual students have a lower drop-out rate, have higher college entrance rates and help lower the achievement gap because students are able to pick up the second language more easily when they are immersed in it. (Text 21)

The term immersion was first used by Canadian "immersion schools" developed in St. Lambert in 1963 (Thomas and Collier, 2012, p. 10). These highly successful programs were mainly for Anglophone students who increased their social and economic mobility by gaining access to French (Thomas and Collier, 2012, p. 10). These programs are typically 90:10 models where majority language students (speakers of English) begin to read in the non-dominant language (French) and gradually add English instruction. Since then this term has been adopted (and recently changed from "bilingual" to "dual language" immersion) in the US for similar types of programs, but then adopted by advocates of English-only approaches. DLE programs with content-integrated language learning where students receive as much exposure to the target language as possible are ideal for students that are majority language speakers because when they leave the classroom, they will still have maximal input in their home language from media, social events, family, etc. However, for minority language students, the situation is different. While society provides a great deal of access to academic English outside of school, much less is provided for the minority language (Thomas and Collier, 2012).

This distinction between immersion for majority speakers versus minority language speakers is not made in the persuasive discourses of DLE, and as a result, readers may not un-
Table 2. Metaphors with target domain ${ }^{3}$ Language/Language learners ${ }^{2}$.

\begin{tabular}{llrr}
\hline Type & Source domain & Totals & Percentage (\%) \\
\hline Dominant & Water e.g., fluent/ly immersed, afloat & 127 & 79.4 \\
Secondary & Gift/resource e.g., gift, cognitive benefits 9 & 5.6 \\
& Object e.g., Losing/lose, preserve & 14 & 8.8 \\
Occasional & Barrier, disease, plant/flower & 10 & 6.3 \\
& & $160^{\mathrm{a}}$ & $100^{\mathrm{b}}$ \\
\hline
\end{tabular}

a. Total number of metaphors.

b. Total percentage.

derstand the difference when they encounter monolingual discourses using the same metaphors to advocate for only proficient English speakers to have access to DLE (and thus ignoring students that need it most). In the following examples a language expert and school principal discuss past, inadequate models for bilingual learning incorporating WATER metaphors of DANGEROUS WATERS and EDUCATION AS RIVER to show how the current model of dual language is different, and therefore better.

- In California, some transitional bilingual programs exist. But children in these programs are generally moved into an all-English classroom as soon as they're deemed ready. "So (they are) really never allowing children to fully develop their primary language," said Cristina Alfaro, a dual language literacy professor at San Diego State University. "And then they are pretty much just put into English and it's back to sink or swim." (Text 1)

- "If you've visited other classrooms where Hmong students are the minority, they're quiet, they're shy, or that's how they've been stereotyped," Vang said. "It's hard to get to know one of your Hmong students when they're in the mainstream classrooms." In the immersion classrooms she said students clamor to participate in new traditions like a Twin Cities-wide Hmong spelling bee to be held at Concordia University May 25. (Text 9)

While the efforts of these educators/experts to show the benefits of DL programs is laudable, mentioning deficits in incomplete/inadequate past models leads to confusion as both multilingual and monolingual discourses use the same lexical choices of immersion/immersed. A look at the ontology of the different WATER metaphors will facilitate a better understanding of how this metaphorical mapping process works to shape public opinion.

\subsection{Ontology of DLE/LANGUAGE AS WATER}

As the excerpts above reveal, both advocates and opponents of DL programs use WATER metaphors, but as Santa Ana has demonstrated, the WATER metaphors for each of these discourses are used very differently and contain opposing ideologies. The most common use of the WATER metaphor in the discourse of DLE examined is LANGUAGE AS WATER, which allows for a positive frame in which to view language. In this view, the perception of WATER as a natural source, something that we need and want to have as much as possible is foregrounded.

With each repetition of the metaphor includes the water's fluid nature, its dynamic character, its ability to form bodies and to carry things. These are the semantic highlightings, with the use of the metaphor, which come to be taken as a natural part of the target domain, LANGUAGE or COMMUNICATION. (Santa Ana, 2002, p. 202). 
In contrast, the less frequently used (in articles analyzed) ENGLISH AS WATER metaphor connects with the EDUCATION AS PATH metaphor and LANGUAGE AS BARRIER. This mapping of WATER was found largely to highlight the negative aspects of past or competing ESL/Sheltered English models, and to represent opposing voices and viewpoints to DLE. In this portrayal, largely referring to English learners (the majority of which are Latinos), education is seen as a PATH (in this case, the path is through a RIVER) in which languages other than English act as barriers, stopping the flow. Here the source semantic domain of RIVER maps characteristics from a river onto the target domain of EDUCATION. In this conceptualization, there is a flowing stream with a beginning and an end that travels a great distance and twists and turns, containing obstructions to the path that may snag the traveler in the current (Santa Ana, 2002). Education is viewed as the current and English learners are the travelers maneuvering the strong flow with the goal of staying in the mainstream, where the current is strong and thus can take them down the PATH to enlightenment, and their eventual destination of learning. The RIVER ontology does not imply any volition on the part of the travelers, as they are simply carried by the current, and will eventually blend with and be permeated by the mainstream. Thus the RIVER metaphor comes with the idea that students must assimilate and "acquiesce to the American worldview as they absorb its sanctioned canon, hallowed national myths, and conventional history." (Santa Ana, 2002, p. 193).

\subsection{Narrative of DLE/LANGUAGE AS WATER}

The resulting narratives of each type of WATER metaphor are quite different. In the first (and most commonly found in this study), students learn language like they absorb water into their bodies. Students' bodies become carriers of the fluid that is language and they become conduits of meaning and communication. The more target language input, the better, as this vital liquid is to be preserved and treasured. Although this metaphor is used mainly in positive contexts, is can be problematic because it allows people to falsely believe that learning an additional language is easy (just as water is absorbed in the body), and that learners are passive in the process. Those in the field of second language acquisition know language learning is a highly complex process as learners pass through a number of stages that require active and consistent language practice in meaningful language tasks and contexts taught by professional educators who are proficient in language, content and pedagogy. All of this is lost when terms such as immersion are used which imply a passive absorption of language much like a paper towel soaking up spilled milk.

The second narrative of ENGLISH AS WATER/EDUCATION AS RIVER paints the picture of students floating down the RIVER of education, hoping to join the others in the mainstream, passively waiting for the ENGLISH current to carry them while losing their own culture and language as they are seen as obstructions to the river's path. This metaphor is used in the articles analyzed as part of an argumentation strategy to demonstrate the superiority of DLE. However, readers may not understand the difference between English immersion and dual language immersion thereby potentially causing confusion. In addition, because the same WATER metaphors are used when referring to negative aspects of past models as when referring to DLE, people will associate the one with the other.

The second dominant metaphor found in the articles was that of DLE AS BUSINESS/FACTORY. These two metaphors were included together because over time the FACTORY model (referred to as INDUSTRY in Johnson (2005b)) has merged into a BUSINESS model, and neoliberal discourse that includes the language of the market is so integrated into daily text and talk that it is easily unnoticed (Mautner, 2010). The following examples are linguistic realizations of the traditional mechanistic view of EDUCATION AS FACTORY, which has become so embedded in public discourse:

- On average, students from the United States do not graduate from high school with the language skills necessary to compete in the global marketplace. (Text 10).

- He said while the program makes it challenging to communicate at times, the long term benefits for students both in the classroom and eventually the workforce make it worthwhile. (Text 16)

- ...the real payoff, according to the school district and others in the field, comes well down the road when they enter a workforce that has an increasing need for bi-lingual speakers. (Text 16).

The examples below reflect the postindustrial age, and the more frequent metaphor of EDUCATION AS BUSINESS used to evaluate the quality of education in terms of profitability:

- "With commerce and globalization, we feel it's important that our students be able to compete and speak more languages," she said. "And that's where the interest is coming in for another language." (Text 5)

- Riverview elementary school principal Al Levin sees the issue as a marketing challenge. (Text 9, referring to recruitment of native English speakers to the Hmong program)

- "I think as we become more and more globally aware, we're realizing that kids need to be prepared to be competitive in world markets," said Principal Jorge Ramirez. (Text 2)

These are persuasive arguments with which experts in the field agree and therefore it is not surprising that this emerged as the second most dominant metaphor in the texts. The metaphors are also reflective of the current economic context (recovery from a recession, many young people worrying about employability) and the infiltration of neoliberal arguments that emphasize the shift in educational philosophy from pedagogical to market values and the abandonment of the social and cooperative ethic in favor of individualist and competitive business models (Block et al., 2012).

\subsection{Ontology of DLE AS BUSINESS/FACTORY}

In order to understand the problem with discourse that calls for our students to enroll in dual language so they may get a better job, or be more competitive on the "job market", we need to understand the process of "marketisation". According to Mautner (2010), marketisation is the "transfer of social and discursive practices from business to other domains" (p. 22). In the BUSINESS metaphor, the market is reified and treated as a thing or person that takes precedent over everything (Mautner, 2010). When we employ the BUSINESS schema, we have producers that employ skilled workers who make products, package them and sell them to customers/clients that they hope will buy the products. Business is marketdriven, and must make a profit to succeed. In order to make a profit, the business must minimize expenses, compete in the global market, grow and expand and producers must pay attention to performance indicators, employ various strategies to identify and address challenges that arise and work as a team to manage its resources. If all of these things are accomplished the business can be dubbed a success. The following examples demonstrate the infiltration of this metaphor (and EDUCATION AS FACTORY) into DLE discourse: 
- The first year of the Dual Language Immersion program has been a success, and the bilingual kindergarten students will move on to the first grade as a new batch of kindergarten students enter the program at Hackett and Robinson Elementary schools, according to Rosamaria Laursen, ELL program manager. (Text 20)

- "We certainly have identified the challenges we have our in program, and it is on us to develop strategies and plans that will address those challenges, and that's what our team will do," he said. (Text 14)

\subsection{Narrative of DLE AS BUSINESS/FACTORY}

The narrative for DLE AS BUSINESS unfolds as follows: DL students and their parents are consumers that buy language education. In order to be successful, they must be skilled learners with skilled teachers that know the latest methodologies. Teachers are knowledge producers that produce proficient language speakers. DL programs must be managed and strategies must be identified to help students to best access the product, language proficiency. This language proficiency is a resource that students can use to market themselves in a globalized world. When we as a community invest in DLE, we are investing in the human capital that language learners possess, and their ability to succeed in the marketplace will be profitable to all.

In the above narrative, the myth is that "the market is always best, and the market is always right" and that logic from the for-profit sector should be universally applied and transferred to educational domains (Mautner, 2010, p. 25). A major problem with the infiltration of business language into DL discourse is that by focusing on material profits rather than cultural cultivation, it influences the way we think about language learning and undermines the benefits of coming together to pursue and create knowledge. The marketization of DLE discourse emerges as one of the dominant metaphors but in actuality represents only one of the benefits of DLE. In contrast to what was found in the DL media discourse, Thomas and Collier (2012)'s recent book lists 20 benefits of DLE and only a few address issues related to the EDUCATION AS BUSINESS metaphor. Some of the noted benefits include more student engagement and interest, fewer behavioral referrals, development of un-activated brain areas and increases in creativity and problem-solving ability, more favorable attitudes toward being bilingual and toward students who are different from themselves, stronger cultural identity and high self-esteem among others.

Although the theme of benefits (besides those associated with business models) was very present in the discourse, it was still less present than the WATER and BUSINESS/FACTORY metaphors and was therefore listed as a secondary metaphor. The metaphor of DLE/LANGUAGE AS GIFT/RESOURCE transfers qualities of gifts to language, such as giving and receiving, being happy and lucky to have this gift, and being able to use the gift for enjoyment and for a useful purpose. Below are a few examples of some of the other benefits highlighted in the articles through the DLE/LANGUAGE AS GIFT/RESOURCE metaphor:

- "This is a gift that Utah is giving its children," said Met. "A gift that you really can't get any other time or any other way." (Text 29)

- "If we have the resources available to us to give the kids multilingualism, bilingualism, why would we not take advantage of that? It's a resource, it's not a detriment," she said. (Text 7)

- "We have more research now that shows students who develop two or three languages to a high level have certain cognitive advantages," said Julie Sugarman, a research associate with the
Center for Applied Linguistics, a Washington, D.C.-based organization. "They do as well or better than their peers in English-only programs." (Text 2)

- Whether responding to a math equation in unison or learning the value of one another's cultures through group projects, Lizano said after a sometimes trying first year in the program, his students are growing exponentially in language acquisition and cultural competency. (Text 16)

- Other benefits are language development and cross-cultural understanding. (Text 4)

Two additional secondary metaphors that are noteworthy were EDUCATION AS CULTIVATION (similar to Santa Ana's finding) and LANGUAGE AS OBJECT. According to Santa Ana (2002), EDUCATION AS CULTIVATION highlights developmental maturation and evokes the personal potential of individual students, and is an excellent alternative to metaphors of EDUCATION AS WATER or BUSINESS. This metaphor carries with it the idea that the child's mind contains the seeds of learning, and must be cultivated with careful tending over a lifetime to reap its full potential (Santa Ana, 2002). Foregrounded here are the teacher's critical role as sower and the school's environment as a fertile and temperate climate in order for the child to sprout (Santa Ana, 2002). The following examples transfer qualities from the source domain of PLANT/FLOWER to DL students and programs.

- The school board is scheduled to discuss the development of the program again in January. "Who knows, maybe it will blossom like Glendale's," Kemp said. (Text 25)

- "My opinion: It will only grow as people understand the value of it," says Bobby Burns, Carrollton-Farmers Branch ISD superintendent. (Text 3)

- "We have seen them flourish because when Spanish comes, they shine," said Linda Richard, who also teaches in the Spring Lake program. (Text 27)

- Principal Vang said the first grader is flourishing. (Text 9)

A final secondary metaphor worth mentioning is that of LANGUAGE AS OBJECT. This metaphor is frequently used in discourse about language (e.g. Velàzquez, 2013) because viewing this abstract concept as something concrete you can hold, touch, keep, lose or preserve, helps to reify it and make it more understandable. The following examples reveal how language is viewed as an object in the articles analyzed and also highlight the status of English as something students must get into, whereas Spanish is something that families are worried about losing:

- She chose the program because it helps keep their identity of who they are, and preserves the language, "so they don't lose it," she said. (Text 28)

- But her mother, who also lives with the family, speaks only Spanish. Blankenship is worried her daughter was losing her Spanish before she enrolled in the dual language immersion program. (Text 1)

- Other California public school programs aimed at English Language Learners have a different goal - to get students into English as quickly as possible. (Text 1 )

\subsection{Other linguistic strategies}

Additional linguistic strategies found to represent DL programs in the articles included the use of metonymy, legitimization strategies such as quoting of elite members of the community, and the inclusion of opposing arguments by using metaphors, deictics and presuppositions. 


\subsubsection{Metonymy}

Metonymy is a concept central to CL that plays an important role in shaping public opinion about events. Metonymy can be defined as a mapping where an element in a frame (the source) provides mental access to a target because there is a perceived connection or association between them (Anon, 2013). Like metaphor, metonymies inevitably highlight some things while they hide others, and are thus useful in shaping the public's opinion about events, actions or people. In the case of metonymies about DLE and DL students, results revealed a variety of ways to refer to DL programs and students. With 15 different tokens found referring to DL programs (including those not already mentioned such as dual language schools, two-way immersion program, $D L E$, dual program, two-way program, dual language teaching and dual immersion language program) it is not surprising that there is so much variety even within one article in the way in which the programs are labeled. For example, in Text 4 , the program is referred to in 6 different ways, Text 10, 4 ways and Text 7, 3. Thus, even though this variety of lexical choices to refer to the programs might be a stylistic choice (e.g. to avoid repetition) there seems to be confusion in the field and in the public sphere as to the appropriate way to refer to these programs and even how to describe them. For instance, of the tokens that referred to the programs as dual language, 60 tokens did not include a hyphen while 34 did (e.g. dual-language). This confusion de-legitimizes the programs due to a lack of standardization (e.g. with the hyphen or without?), which leads to the impression that these programs are different from each other in some way, when in reality they are referring to the same thing (e.g. dual-language versus dual language or dual language immersion). ${ }^{2}$ As far as how language learners in these programs are represented, a majority of tokens referring to students whose first language was Spanish referred to them in regards to English, such as English learners, English language learners, non-native English speakers or limited English learners (71\%) while only $29 \%$ referred to the students in relation to their mother tongue (e.g. Spanish-speaking, native Spanish speakers). This supports Santa Ana (2002)'s findings showing that languages other than English are frequently seen as barriers while English possesses a higher and more central status. This subtle (and hardly noticed) difference in the metonymies reveals an underlying ideology that still views bilinguals (particularly Latinos) in a deficit frame in relation to English as opposed to their dominant language (in which they have higher proficiency than their English-speaking peers). In contrast, students whose first language was English were presented 100\% of the time from the perspective of their mother tongue ${ }^{3}$ (e.g. English speaking and native English speakers) and thus not from a deficient viewpoint. To understand the difference, imagine if these students were referred to as non-Spanish speakers or Spanish learners, (which they are in a Spanish dual language setting). This Spanish-centered view would highlight their deficit (Spanish) or the subject that they are learning (Spanish), and would have a completely different effect on the readers of these articles.

\subsubsection{Legitimization}

Articles analyzed also shed light on how DL programs are legitimized through quotations from researchers as well as elite members of the educational community. These quotations and comments are used in the articles repeatedly to legitimize the growth of the programs in the local context such as in the following example:

- "We have more research now that shows students who develop two or three languages to a high level have certain cognitive advantages," said Julie Sugarman, a research associate with the Center for Applied Linguistics, a Washington, D.C.based organization. (Text 2)

- "Nationwide, we think every one of the nation's 16,000 school districts ought to be considering dual-language," said Wayne Thomas, a professor emeritus at George Mason University. (Text 4)

Although most of the texts contained quotations supporting the programs such as those in the above examples, only $38 \%$ of texts contained quotations from researchers or language experts. Although slightly higher, this finding is similar to that of McQuillan and Tse (1996), where $24 \%$ of articles contained information about scientific research related to dual language. Although 16 years later than McQuillan and Tse (1996)'s article, this analysis supports their findings that more evidence based studies be presented in media discourse about dual language.

\subsubsection{Monolingual discourses}

Traces of monolingual discourses were also found in many of the texts, ${ }^{4} 34 \%$ of which referred to challenges, controversy or problems associated with the programs. These discourses were presented through a variety of linguistic strategies including metaphors of WAR, FORCE and NATURAL DISASTER (mentioned in Table 1), presuppositions and use of deictics. Monolingual discourses in the form of presuppositions were presented in the discourse as given information, not requiring definition or legitimization (Machin and Mayr, 2012). Here are a few examples:

- Unlike the original bilingual classes, which catered to non-native English speakers, the new programs are designed to blend English speakers and non-native speakers, to allow everyone to learn a second language. (Text 2)

- Despite these large numbers, however, there are only around 400 two-way immersion programs in the country. The fact is, it is unrealistic to offer these programs at all schools-especially because there is not a need. (Text 10)

- "Bilingualism has made a comeback," said Tom Kissinger, director of elementary education for Burbank Unified. (Text 25)

The above statements contain presuppositions that contain subtle ideologies that reflect the history of monolingual discourses and opposition to past bilingual education as well as misinformation and are "used in order to build a basis for what sounds like a logical argument" (Machin and Mayr, 2012, p. 154). For example, Text 2 uses the expression $\mathrm{ca}$ tered to non-native English speakers, which implies that the programs of the past not only cared about Spanish-speaking students but went to extravagant lengths to accommodate them

2. Those who use the hyphen (e.g. dual-language education) most likely base this decision on rules such as those found at http://www.apastyle. org/learn/faqs/when-use-hyphen.aspx , which say to include a hyphen when there is a potentially ambiguous compound adjective. In this case, proponents of not using the hyphen could argue that the term has become so conventionalized that there is no longer ambiguity as to what the term refers to (e.g. it is clear that it is not referring to two programs but language programs that feature two languages). Regardless of the reasons why the hyphen is used or not used, it creates confusion.

3. The term non-Hmong students was used twice in Text 28, but it is not clear that these students were native English speakers as the text mentions one student who was a speaker of Vietnamese.

4. Monolingual discourses were largely present when referring to those who oppose the programs or past (unsuccessful) models of the programs, but not in terms of current programs and their success. In the case of discourse about current programs and successful models, multilingual discourse prevails in which language is seen as a resource and not a deficit. 
(as opposed to respecting linguistic rights). Text 10 states that there is no need for two-way programs at all schools (meaning not all schools have native speakers of the target languages). However, this implies that the two-way programs are needed mostly to help non-native English speakers when in fact, this is not the case. While DL programs should serve English learners first and foremost as they are the students typically placed at greatest risk (Thomas and Collier, 2012) all students can benefit from two-way programs. Although both two-way and one-way programs are highly effective means of language education, two-way programs have been proven to be superior to one-way as measured by increased oral proficiency and cultural knowledge students obtained (regardless of their native language) from the intercultural interactions with native speakers of their target language (Menke, 2012). Finally, the use of comeback from Text 25 to refer to bilingualism draws on past monolingual discourses (such as in McQuillan and Tse's study) in which bilingualism was considered a deficit, and not a resource. In addition to many pre-suppositions about language programs, many texts present opposing views by explaining parent critiques of the programs such as in the following comments:

- "Who would think that children should be forced from their neighborhood school because they speak the native language of the United States?" (Text 6, from a press released written by a parent wanting English-only education for her child)

- "The main criticism that I have here is that, "This is America. We speak English. Why are we teaching kids other languages?'" she said. But Miller said she hoped her school's success can dispel any doubts. (Text 7)

- "There was a group that thought, why would you want to teach kids in Spanish - this is America," said Tina Brady, assistant superintendent at the Lakeside School District. "Now, we have waiting lists to get in." (Text 11)

Deictics (pronouns such as this, these, our, their used for purposes of positioning) were also used in the examples from Text 7 and Text 11 in which we or you is evoked by opposing parents (and quoted by proponents of the programs such as the assistant superintendent and school principal) for the purposes of separating opponents of the programs from proponents. Pronouns such as "we" and "our" are "most revealing of the boundaries separating Self and Other" (Petersoo, 2007, p. 420). They are also an important aspect of national identity formation and maintenance and "should not be underestimated in unconsciously picking up the 'national' references hidden behind these small words" (Petersoo, 2007, p. 432) such as in This is America - we speak English. People constantly "adopt and defend their positions, and accept or confront the positions of others through positioning", which is largely accomplished by the use of discursive devices such as the pronouns mentioned above (Dedaić and Dale, 2012). Deictics were also used to position the readers alongside the proponents of the program and to appeal to the moral values of the readers. The following example shows how we is used (as in we, the people living in the state of Texas and the speaker) to align Texans alongside the superintendent's ideas about bilingualism and create a collective unity among the people of Texas and this issue:

- "My opinion: It will only grow as people understand the value of it," says Bobby Burns, Carrollton-Farmers Branch ISD superintendent. "By far, it is the right thing to do for students. For Texas, we need to be a bilingual state." (Text 3)

The use of the inclusive we (above) combined with the prepositional phrase For Texas not only creates speaker-lis- tener unanimity among fellow Texans (playing upon the wellknown Lone Star State pride), but also allows Texans to position themselves as bilingual. In addition, it is exclusive in that it does not include other states implying that Texas is different. Had the speaker said "Texas needs to be a bilingual state" instead of For Texas, we need to be a bilingual state, the same connotation of unity and inclusion between the speaker and the local readers would not have occurred and the persuasive nature of his utterance would have been reduced.

In regards to the inclusion of opposing arguments in general, according to George Lakoff, "When we negate a frame, we evoke a frame" (2004, p. 1). Thus, even though these opposing arguments (placed in the context of promotion for DL programs and including those mentioned in the WATER section) were most likely meant to give a well-rounded view of the proponents and opponents, introduction of monolingual discourses such as This is America, we speak English, etc. does not promote the multilingual discourse that advocates and policymakers wished to demonstrate by publishing the article. Often information from opposing sides is inaccurate or misleading (such as in the example from Text 6, about English being the native language of the United States) and placement of such opposing views in the discourse does not benefit the cause.

\section{Discussion/Conclusion}

This critical linguistic analysis has offered a systematic examination of the linguistic elements of 29 articles focused on dual language programs. Analysis has demonstrated how linguistic strategies such as the use of metaphor, metonymy, legitimization, and inclusion of opposing arguments through metaphor, presuppositions and deictics work to present positive and negative images of dual language programs revealing the presence of both multilingual and monolingual discourses. Dominant metaphors were found that deeply affect the way the public views DL programs and included DLE AS WATER, BUSINESS/FACTORY and secondary metaphors, such as DLE/LANGUAGE AS GIFT/RESOURCE and CULTIVATION. Because the authors wanted to include a reasoned and tightly selected data set, the narrow time frame of 18 months limited the results to allow for an up-to-date view of the nature of media discourse. This allows an insider's view of the current state (as of 2013) of media discourse about DLE. It is suggested, however, that further diachronic research focused on the change in media discourse over time be undertaken in order to compare and gain a more balanced picture of the types of language programs that are offered in the US.

In light of the findings of this study, several recommendations have emerged regarding how communication about these programs can be improved that could be of benefit to educational policymakers, educators/administrators and language experts. First, we recommend that those responsible for communicating to the public or creating policies about DLE (whether it be in the form of sending out public announcements or speaking to journalists) avoid water metaphors. One easy way to accomplish this would be to establish at a dual language conference or through a professional journal/listserv a standard name for programs (we recommend the simple "dual language education" or "dual language program" with no hyphen) that eliminates the word "immersion" that has been co-opted by opponents of DLE. This will avoid confusion about the nature of the programs and the process of language learning itself. Moreover, it will assist journalists and their readers to better understand how to refer to these programs (dual-language or dual language?) when discussing and describing them. In addition, when referring to DL learners, English should be given a more equal status among other 
languages by changing metonymies such as "non-native English speakers" to "native Spanish speakers". Second, educators and language researchers should refrain from mentioning opposing views when talking to journalists in order to avoid evoking negative frames, although this will not always change how the journalist ends up writing about the programs (Lakoff, G., personal communication, August 8, 2013). Finally, whenever possible, those speaking to the media should highlight and forefront benefits of these programs that appeal to moral values (e.g. - "It's the right thing to do"), and intercultural competency as opposed to financial/economical success. Emphasizing these aspects will underscore the numerous benefits of these programs for ALL learners, particularly for English learners who need it most. As Collier and Thomas (2004) assert, "Clearly dual language education is a school reform whose time has come. It is a school model that even the English-only advocates endorse, because it is an inclusive model for all students, and all student groups benefit from participating" (p. 20). Now is the optimal time to expand on and improve communication about dual language education to the public through pluralistic and inclusive media discourses that encourage the preparation of all students for the 21st century.

\section{Appendix A. Texts used in the corpus}

Text 1: Replogle, J., 2012, February 2. The Latino gap: DL programs offer hope. KPBS Public Broadcasting. Retrieved April 25, 2013, from http://www.kpbs.org/news/2012/feb/02/ latino-gap-dual-language-programs-offer-hope/.

Text 2: Su, E.Y., 2012, March 22. DL programs growing in popularity across California. Huffington Post. Retrieved April 25, 2013, from http:// www.huffingtonpost.com/2012/03/22/dual-languageprograms-gr_n 1372804.html.

Text 3: Unmuth, K. L., 2012, February 28. Dual-language programs expanding rapidly in Texas. Latino Ed Beat. Retrieved April 25, 2013, from http:/ / latinoedbeat.org/2012/02/28/ dual-language-programs-expanding-rapidly-in-texas/.

Text 4: Solis, D., 2012, July 31. Dual-language programs growing in Dallas-area schools, across state. Dallasnews.com. Retrieved April 25, 2013, from http:/ / www.dallasnews.com/news/education/headlines/20120225-dual-language-programs-growing-indallas-area-schools-across-state.ece.

Text 5: Whitehead, T., 2012, May 14. Schools adopt dual language program. Valley Morning Star. Retrieved April 25, 2013, from http:// www.valleymorningstar.com/news/article_041d93965726-5720-98ca-6bd187d627eb.html.

Text 6: Possible changes to dual language program spark debate: proposal by Encinitas school district would consolidate Spanish immersion program at Capri Elementary School (2012, March 14). ABC 10 News. Retrieved April 25, 2013, from http://www.10news.com/news/ possible-changes-to-dual-language-program-spark-debate.

Text 7: Lee, C., 2012, February 15. Dual-language program in Irving highlighted. NBC News. Retrieved April 25, 2013, from http:// www.nbcdfw.com/news/local/Dual-Language-Program-in-Irving-Highlighted-139396958.html.

Text 8: Iyamba, N., 2012, March 7. Will Utah's immersion language programs grow or stagnate? KSL.com. Retrieved April 25, 2013, from http:// www.ksl.com/?nid=148\&sid=19499926.

Text 9: Brown, A., 2012, May 14. St. Paul Hmong two-way immersion programs face challenges of enrolling non-Hmong students, developing curriculum. Twin Cities Daily Planet. Retrieved April 25, 2013, from http://www.tcdailyplanet.net/ news/2012/05/14/st-paul-hmong-two-way-immersion-programs-face-challenges-enrolling-non-hmong-student.

Text 10: Ellenby, J., 2012, May 14. The need for dual language immersión. Partisans.org. Retrieved April 25, 2013, from http://www. partisans.org/2012/05/language-immersion.

Text 11: Magee, M., 2012, January 23. Learning in multiple languages: more parents demand immersion programs to help children thrive in a global society. U-T San Diego. Retrieved April 25, 2013, from http://www.utsandiego.com/news/2012/jan/23/ learning-in-multiple-languages $/$.

Text 12: Bucksten, D., 2013, April 17. Dual language program challenges students to succeed. ChicagoTribune.com. Retrieved April 25, 2013, from http://www.chicagotribune.com/news/local/suburbs/ct-tl-lk-0418-d112-dual-language-20130417,0,6411909.story.

Text 13: Conner, E., 2013, March 17. Dual-language classes interest grows in Natrona County, Wyoming. Trib.com. Retrieved April 25, 2013, from http://trib.com/news/local/casper/duallanguage-classes-interest-grows-in-natrona-county-wyoming/ article 1daa05f6-6232-58d2-bf54-b664b9a3bb20.html.

Text 14: Jenco, M., 2013, January 11. School official questions effectiveness of dual language program. ChicagoTribune.com. Retrieved April 25, 2013, from http://articles.chicagotribune. com/2013-01-11/news/ct-tl-naperville-d203-dual-language-review-20130111 1 dual-language-program-national-foreign-language-center-english-in-two-years.

Text 15: Forcella, T., 2013, April 6. Dual language prepares lifelong learners. The Chapel Hill News. Retrieved April 25, 2013, from http://www.chapelhillnews.com/2013/04/06/75755/dual-language-prepares-lifelong.html.

Text 16: Suman, J., 2014, April 5. Two-way teaching | BSD dual-language program providing curriculum for culturally changing future. BellevueReporter.com. Retrieved April 25, 2013, from http://www.bellevuereporter.com/news/201096141.html.

Text 17: Conner, E., 2013, April 7. Dual-language immersion could start in 2014. Trib.com. Retrieved April 25, 2013, from http:// trib.com/news/local/casper/dual-language-immersion-couldstart-in/article_a18273db-f7dc-5b55-bc95-14314fabce6e.html.

Text 18: Miller, E. M., 2013, March 12. D300 weighs expanding dual language to middle school. The Courier-News. Retrieved April 25, 2013, from http:/ / couriernews.suntimes.com/ news/18796223-418/d300-considers-expanding-dual-languageto-middle-school.html.

Text 19: DL programs will benefit students (2013, February 19). The Daily Tar Heel. Retrieved April 25, 2013, from http:// www.dailytarheel.com/article/2013/02/512423a0510b6

Text 20: Gavan, H., 2013, March 27. Dual language immersion program a hit. Beloit Daily News. Retrieved April 25, 2013, from http://www.beloitdailynews.com/news/dual-language-immersion-program-a-hit/article 467eb3e0-96ef-11e2-ab070019bb2963f4.html.

Text 21: Pursinger, G., 2013, February 14. Bridgeport says 'hola' to dual-language program. PortlandTribune.com. Retrieved April 25, 2013, from http:// portlandtribune.com/ttt/89-news/128290bridgeport-says-hola-to-dual-language-program.

Text 22: Beckman, H., 2013, January 12. D203 board members question dual-language program's results. Naperville Sun. Retrieved April 25, 2013, from http://napervillesun.suntimes.com/ news/17502434-418/d203-board-members-question-dual-language-programs-results.html.

Text 23: Pollreisz, A., 2013, January 14. Dual-language immersion discussed at NCSD board meeting. K2radio. com. Retrieved April 25, 2013, from http://k2radio.com/ dual-language-immersion-considered-at-ncsd-board-meeting/.

Text 24: Warth, G., 2013, January 15. OUSD increases building fees, plans dual-language kindergarten. U-T San Diego. Retrieved April 25, 2013, from http://www.utsandiego.com/news/2013/ jan/15/ousd-increases-building-fees/.

Text 25: Corrigan, K., 2012, November 20. Burbank unified moves toward dual-language learning. The Burbank Leader. Retrieved April 25, 2013, from http://articles.burbankleader.com/2012-11-20/the818now/tn-818-1120-burbank-unified-moves-toward-duallanguage-learning 1 dual-immersion-dual-language-school-board.

Text 26: Llopis-Jepsen, C., 2013, January 3. Parents make impassioned plea for dual-language program at Whitson Elementary: Spanish-English program offered in kindergarten through third grade. The Topeka Capital-Journal. Retrieved April 25, 2013, from http:/ / cjonline.com/news/2013-01-03/parents-make-impassioned-plea-dual-language-program-whitson-elementary. 
Text 27: Rodriguez, E., 2012, January 6. Dual-language classes on the rise in Central Florida. Orlando Sentinel. Retrieved April 25, 2013, from http://articles.orlandosentinel.com/2012-01-06/features/os-dual-language-20120106_1_dual-language-classes-second-language-english.

Text 28: Regan, S., 2013, January 11. St. Paul's Jackson Magnet School: first in nation with Hmong dual language program. Twin Cities Daily Planet. Retrieved April 25, 2013, from http://www.tcdailyplanet.net/news/2013/01/11/ jacksons-hmong-dual-immersion-program.

Text 29: Wimmer, N., 2012, December 3. Utah immersion program the envy of the nation. KSL.com. Retrieved April 25, 2013, from http:// www.ksl.com/?nid=148\&sid=23233541.

\section{References}

Block et al., 2012 • D. Block, J. Gray, \& M. Holborow, Neoliberalism and Applied Linguistics, Routledge, London (2012)

Capetillo-Ponce, 2002 • P. Capetillo-Ponce, Challenges to multiculturalism, New England Journal of Public Policy, 20 (2002), pp. 139-147

Center for Applied Linguistics, 2012 - Center for Applied Linguistics, 2012. Directory of two-way immersion programs in the U.S; online: http://www.cal.org/twi/directory/

Collier and Thomas, $2004 \bullet \mathrm{V}$. Collier, W. P. Thomas, The astounding effectiveness of DLE for all, NABE Journal of Research and Practice, 2 (1) (2004), pp. 1-20

Dedaić and Dale, 2012 - M. Dedaić, K. Dale, Mediated collaborative positioning: The case of prisoner blogs, Discourse, Context and Media, 1 (2012), pp. 20-31

de Jong, 2013 - E. J. de Jong, Policy discourses and U.S. language in education policies, Peabody Journal of Education, 88 (1) (2013), pp. 98-111

Fairclough, 2000 - N. Fairclough, New Labour, New Language? Routledge, London and New York (2000)

Fauconnier, 1999 - G. Fauconnier, Methods and generalizations, in T. Janssen \& G. Redeker (eds.), Cognitive Linguistics: Foundations, Scope and Methodology, Mouton De Gruyter, Berlin (1999), pp. 95-128

Fauconnier, 2002 • G. Fauconnier, The Way We Think: Conceptual Blending and the Mind's Hidden Complexities, Basic Books, New York (2002)

Anon., 2013 - Anonymous, The ideologies behind newspaper crime reports of Latinos and Wall Street/CEOs: A critical analysis of metonymy in text and image, Critical Discourse Studies, Special Issue (2013), pp. 1-21

Foucault, 1981 - M. Foucault, The order of discourse, in R. Young (ed.), Untying the Text: A Post-Structural Anthology, Routledge \& Kegan Paul, Boston (1981), pp. 48-78

Fowler, 1991 - R. Fowler, Language in the News: Discourse and Ideology in the Press, Routledge, London (1991)

Galindo, 1997 - R. Galindo, Language wars: the ideological dimensions of the debates on bilingual education, Bilingual Research Journal, 21 (1997), pp. 103-141

Gee, 2011 - J. Gee, An Introduction to Discourse Analysis: Theory and Method, Routledge, New York (2011)

Hart, 2010 - C. Hart, Critical Discourse Analysis and Cognitive Science: New Perspectives on Immigration Discourse, Palgrave, London (2010)

Heath, 1992 - S. B. Heath, Why no official tongue?, in J. Crawford (ed.), Language Loyalties: A Source Book on the Official English Controversy, University of Chicago Press, Chicago and London (1992), pp. 20-31

Hill, 2001 - J. Hill, The racializing function of language panics, in R. D. Gonzales \& I. Melis (eds.), Language Ideologies: Critical Perspectives on the Official English Movement: History, Theory And Policy, vol. 2, National Council of Teachers of English and Lawrence Erlbaum Associates, Urbana, IL and Mahwah, NJ (2001), pp. 245-267

Johnson, 2005a • E. Johnson, War in the media: metaphors, ideology and the formation of language policy, Bilingual Research Journal, 29 (3) (2005), pp. 621-729

Johnson, 2005b - E. Johnson, Proposition 203: a critical metaphor analysis, Bilingual Research Journal, 29 (1) (2005), pp. 69-84

Krashen, $2004 \cdot$ Krashen, S., Let's tell the public the truth about bilin- gual education, 2004; online: http://www.sdkrashen.com/articles/ tell the truth/all.html

Kövecses, 2006 - Z. Kövecses, Language, Mind, and Culture: A Practical Introduction, Oxford University Press, Oxford (2006)

Language Spoken at Home, 2011 -Language Spoken at Home, 2011 American Community Survey; online: http://factfinder2. census.gov/faces/tableservices/jsf/pages/productview. xhtml?pid=ACS_11_1YR S1601\&prodType=table

Lakoff and Johnson, $\mathbf{1 9 8 0} \bullet$ G. Lakoff, M. Johnson, Metaphors We Live By, The University of Chicago Press, Chicago and London (1980)

Lesow-Hurley, 2013 -J. Lesow-Hurley, Foundations of Dual Language Instruction, Pearson, Boston (2013)

Macedo et al., 2003 -D. Macedo, B. Dendrinos, P. Gounari, The Hegemony of English, Paradigm, Boulder, CO (2003)

Machin and Mayr, 2012 -D. Machin, A. Mayr, How to Do Critical Discourse Analysis: A Multimodal Introduction, Sage, London (2012)

Mautner, 2010 •G. Mautner, Language and the Market Society: Critical Reflections on Discourse and Dominance, Sage, London (2010)

McCarty, 2004 •T. McCarty, 2004. Dangerous difference: A critical-historical analysis of language education policies in the United States. In: J. W. Tollefson \& A. B. Tsui (eds.), Medium of Instruction Policies. Which Agenda? Whose Agenda? (pp. 71-93).

McQuillan and Tse, $1996 \bullet \mathrm{J}$. McQuillan, L. Tse, Does research matter? An analysis of media opinion on bilingual education, 1984-1994, The Bilingual Research Journal, 20 (1) (1996), pp. 1-27

Media Alliance, $1998 \cdot$ Media Alliance, 1998. New study finds omissions in California media coverage of Proposition 227; online: http:// www.humnet.ucla.edu/humnet/linguistics/people/grads/ macswan/unz.htm

Menke, 2012 • M. Menke, 2012, October. Exploring the pronunciation identity link of Spanish immersion learners. Paper session presented at the Fourth International Immersion Conferences, St. Paul, MN.

Petersoo, 2007 - P. Petersoo, What does 'we' mean? National deixis in the media, Journal of Language and Politics, 6 (3) (2007), pp. 419-436

Robinson et al., 2006 • J. P. Robinson, W. P. Rivers, R. D. Brecht, Demographic and sociopolitical predictors of American attitudes towards foreign language policy, Language Policy, 5 (4) (2006), pp. $419-440$

Santa Ana, 2002 - O. Santa Ana, Brown Tide Rising: Metaphors of Latinos in Contemporary American Public Discourse, University of Texas Press, Austin (2002)

Scollon, 2001 - R. Scollon, Mediated Discourse as Social Interaction, Longman, London (2001)

Slingerland, 2004 - E. Slingerland, Conceptual metaphor theory as methodology for comparative religion, Journal of the American Academy of Religion, 72 (1) (2004), pp. 1-31

Skutnabb-Kangas et al., 2009 • T. Skutnabb-Kangas, R. Phillipson, A. K. Mohanty, M. Panda, Social Justice through Multilingual Education, Multilingual Matters, Bristol (2009), pp. 19-35

Thomas and Collier, 2012 - W. Thomas, V. Collier, Dual Language Education for a Transformed World, Fuente Press, Albuquerque, NM (2012)

van Dijk, 1993 - T. van Dijk, Principles of Critical Discourse Analysis, Discourse and Society, 4 (2) (1993), pp. 249-283

van Dijk, 1997 - T. van Dijk, Discourse as Structure and Process of Discourse Studies: A Multidisciplinary Introduction, vol. 1, Sage, London (1997)

van Dijk, 2001 - T. van Dijk, Critical discourse analysis, in D. Schiffrin, D. Tannen, H. E. Hamilton (eds.), The Handbook of Discourse Analysis, Blackwell, Oxford (2001), pp. 352-371

Velàzquez, 2013 • I. Velàzquez, Individual discourse, language ideology and Spanish transmission in El Paso, Texas, Critical Discourse Analysis, 10 (3) (2013), pp. 245-261

Wright, 2005 -W. E. Wright, The political spectacle of Arizona's Proposition 203, Educational Policy, 19 (2005), pp. 662-700

Wodak, $2001 \cdot R$. Wodak, The discourse-historical approach, in R. Wodak \& M. Meyer (eds.), Methods of Critical Discourse Analysis, Sage, London (2001), pp. 87-122 